Authors' pre-proof. Article published in International Journal of Industrial Ergonomics vol. 71, pp. 8-13. https://doi.org/10.1016/j.ergon.2019.01.011

(c) 2019. This manuscript version is made available under the CC-BY-NC-ND 4.0 license http://creativecommons.org/licenses/by-nc-nd/4.0/

\title{
Aviation deicing workers, global risk assessment of musculoskeletal injuries
}

S. Nadeau $^{\mathrm{a}, *}$

sylvie.nadeau@etsmtl.ca

\section{H. Salmanzadeh}

M. Ahmadi

K. Landau ${ }^{\mathrm{a}, \mathrm{d}}$

aMechanical Engineering Department, École de technologie supérieure, Montreal, Canada

bIndustrial Engineering Department, K.N. Toosi University of Technology, Tehran, Iran

${ }^{\mathbf{c} S c h o o l ~ o f ~ P u b l i c ~ H e a l t h, ~ T e h r a n ~ U n i v e r s i t y ~ o f ~ M e d i c a l ~ S c i e n c e s, ~ T e h r a n, ~ I r a n ~}$

dInstitute of Ergonomics and Human Factors, Technische Universität, Darmstadt, Germany

${ }^{*}$ Corresponding author. École de technologie supérieure, 1100, Rue Notre-Dame Ouest, Montréal, QC, H3C 1K3, Canada.

Abstract

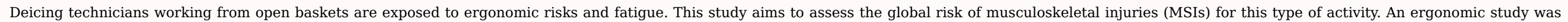

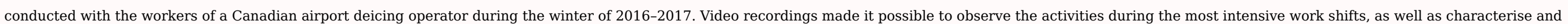

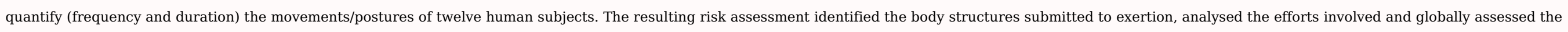
forces exerted on the spine and upper limbs. This global risk assessment leads to the conclusion that the risks to the upper limbs are preoccupying and must be examined further.

Keywords: Deicing; Ergonomics; Musculoskeletal injury; Risk assessment

\section{Introduction}

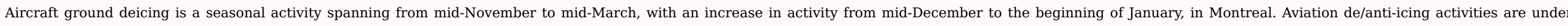

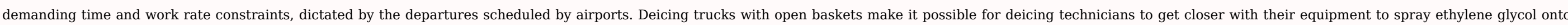

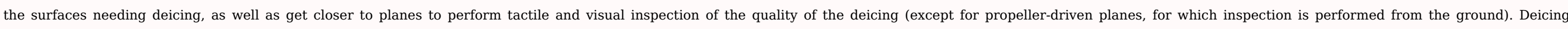

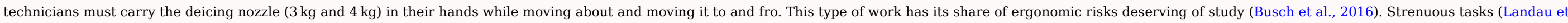

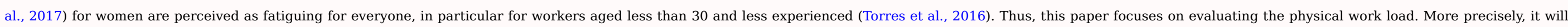
focus on the global risk assessment of musculoskeletal injury (back and upper limbs) that could stem from the work postures and movements of deicing technicians working in open baskets.

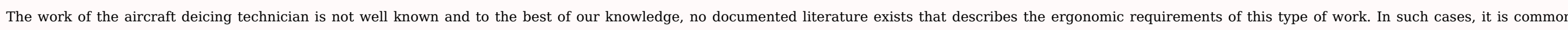

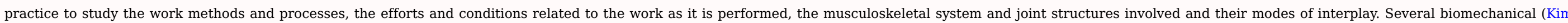

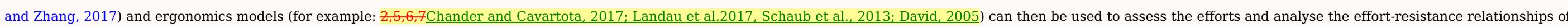

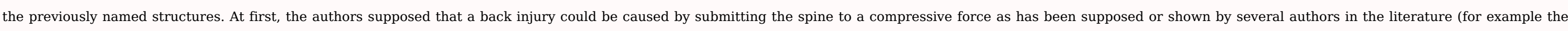

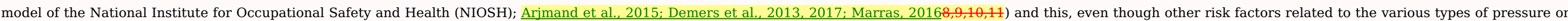




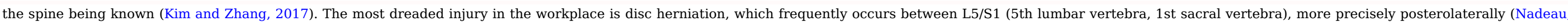
2001). The lesionnal mechanisms that cause a herniated disc are trunk rotation with lateral flexion (Demers et al., 2013, 2017; Nadeau, 2001; Nadeau et al., 2004).

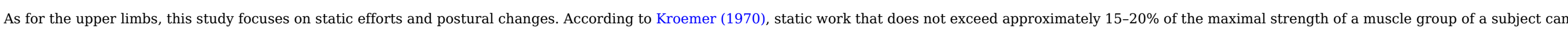

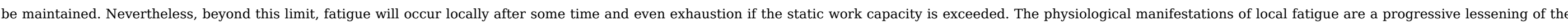

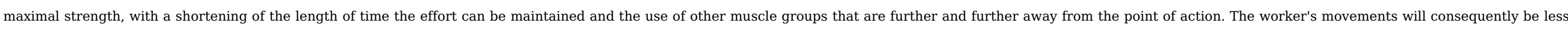
and less precise in terms of positioning, the line of movement will widen and the muscle response time will increase.

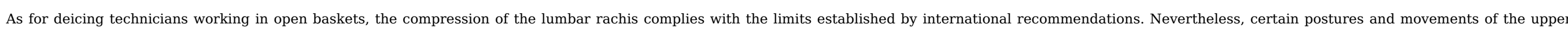
limbs are preoccupying. Further study of the exertion required by the deicing hand-arm-nozzle system and spine is necessary, in particular regarding the grip of the nozzles

\section{Methodology}

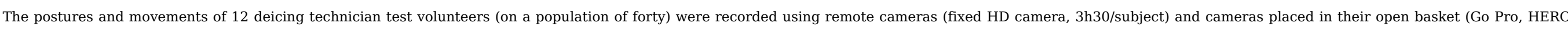

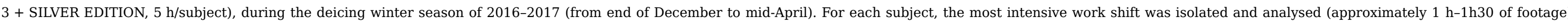

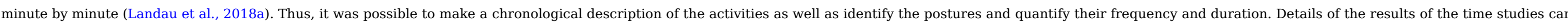

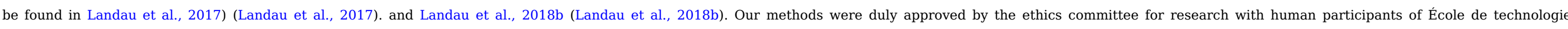
supérieure.

The risk assessment for musculoskeletal injuries was conducted in four stages:

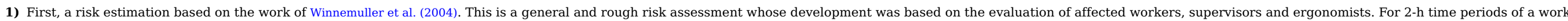

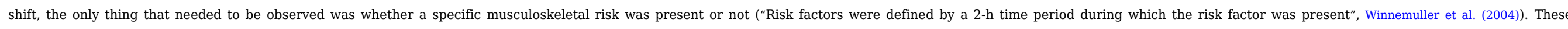
assessments are based on the Washington State Ergonomics Rule of 2002/03 (for an updated review of this, see Park, 2016 (Park, 2016)).

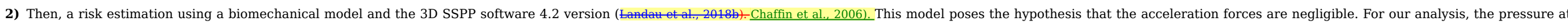

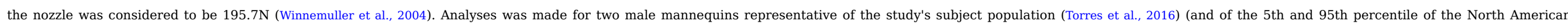

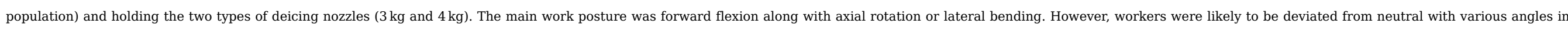
one or more directions. All possible postures and deviations were taken into account in order to make a confident prediction:

a) Case A - height: $165 \mathrm{~cm}$, weight: $65 \mathrm{~kg}$;

b) Case B - height: $193 \mathrm{~cm}$, weight: $95 \mathrm{~kg}$

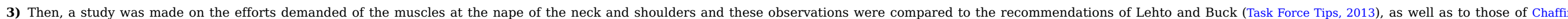
(1973).

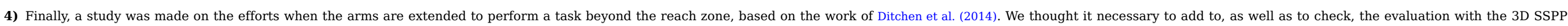
model using the calculations according to Ditchen et al. (2014) as unusual hand-arm-shoulder strains could occur within the thresholds of the reach zones while spraying deicing fluids.

\section{Results}

The population studied is composed of 12 subjects: 10 men and 2 women. The population's main characteristics are described in Table 1.

Table 1 Main characteristics of the population under study. 


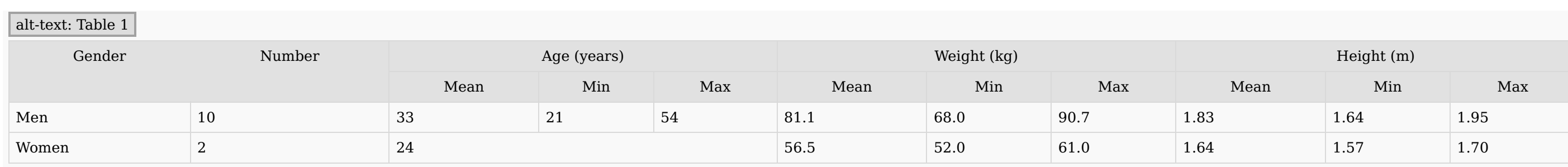

Open basket deicing technicians work in postures that are not optimal from an ergonomic perspective, for example:

- Sagittal flexion sometimes up to $90^{\circ}$. The angle of flexion depends on the workers' height and their work methods

- Lateral flexion sometimes up to $25^{\circ}$. Lateral flexion often occurs when workers are spraying de/anti-icing fluids:

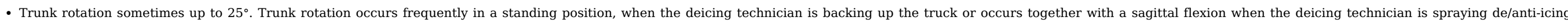
fluids;

- Arms completely extended forward. When spraying type IV deicing fluid, the worker's arms are extended (to the maximum limit of the reach zone) frontwards;

- Forearms flexion sometimes up to $60^{\circ}$;

- Head strongly bent either in the sagittal or lateral plane or in rotation.

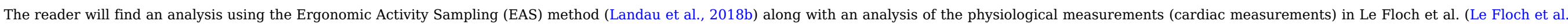
2018).

\subsection{Model of Winnemuller et al. (Winnemuller et al. (2004)}

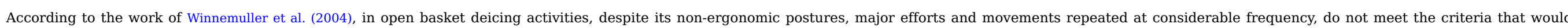

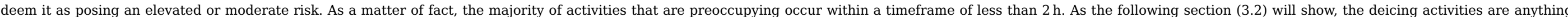
but risk-free. The 0/l assessment according to Winnemuller et al. (2004) ("present within a 2-h time period or not") is therefore not suitable for our purposes.

\subsection{Analysis of the exertion on the spinal column, model of Chaffin et al. (Chaffin, 1973)}

Using 3D SSPP software, analysing 27 different postures with two different nozzles, the following was found:

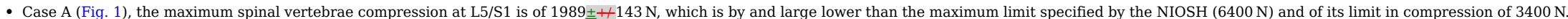

- Case B (Fig. 2), the maximum spinal vertebrae compression at L5/S1 is of 2915 $\pm+219 \mathrm{~N}$, which is lower than the maximum recommended limit of the NIOSH (6400 N) and of its limit in compression of $3400 \mathrm{~N}$.

- Spinal vertebrae compression at L5/S1 is maximum when the workers assume a posture of $60^{\circ}$ forward flexion, $15^{\circ}$ axial rotation, and $15^{\circ}$ lateral bending simultaneously whether they use the 3 or $4 \mathrm{~kg}$ nozzles 


\begin{tabular}{|c|c|c|c|c|c|c|c|}
\hline \multirow[b]{2}{*}{$\begin{array}{c}\text { Axial } \\
\text { rotation }\end{array}$} & \multirow[b]{2}{*}{$\begin{array}{l}\text { Lateral } \\
\text { bending }\end{array}$} & \multicolumn{3}{|c|}{ nozzle's weight: $3 \mathrm{~kg}$} & \multicolumn{3}{|c|}{ nozzle's weight: $4 \mathrm{~kg}$} \\
\hline & & Flexion $=35^{\circ}$ & Flexion $=60^{\circ}$ & Flexion $=80^{\circ}$ & Flexion $=35^{\circ}$ & Flexion $=60^{\circ}$ & Flexion $=80^{\circ}$ \\
\hline \multirow{3}{*}{$0^{\circ}$} & $0^{\circ}$ & $1059 \mathrm{~N}$ & $1700 \mathrm{~N}$ & $1100 \mathrm{~N}$ & $1450 \mathrm{~N}$ & $1631 \mathrm{~N}$ & $1126 \mathrm{~N}$ \\
\hline & $15^{\circ}$ & $1470 \mathrm{~N}$ & $1615 \mathrm{~N}$ & $1057 \mathrm{~N}$ & $1417 \mathrm{~N}$ & $1625 \mathrm{~N}$ & $1086 \mathrm{~N}$ \\
\hline & $25^{\circ}$ & $1400 \mathrm{~N}$ & $1644 \mathrm{~N}$ & $1110 \mathrm{~N}$ & $1493 \mathrm{~N}$ & $1505 \mathrm{~N}$ & $1140 \mathrm{~N}$ \\
\hline \multirow{3}{*}{$15^{\circ}$} & $0^{\circ}$ & $1477 \mathrm{~N}$ & $1600 \mathrm{~N}$ & $1543 \mathrm{~N}$ & $1513 \mathrm{~N}$ & $1600 \mathrm{~N}$ & $1583 \mathrm{~N}$ \\
\hline & $15^{\circ}$ & $1495 \mathrm{~N}$ & $1989 \mathrm{~N}$ & $1696 \mathrm{~N}$ & $1590 \mathrm{~N}$ & $1952 \mathrm{~N}$ & $1750 \mathrm{~N}$ \\
\hline & $25^{\circ}$ & $1515 \mathrm{~N}$ & $1642 \mathrm{~N}$ & $1524 \mathrm{~N}$ & $1600 \mathrm{~N}$ & $1775 \mathrm{~N}$ & $1548 \mathrm{~N}$ \\
\hline \multirow{3}{*}{$25^{\circ}$} & $0^{\circ}$ & $1463 \mathrm{~N}$ & $1836 \mathrm{~N}$ & $1500 \mathrm{~N}$ & $1550 \mathrm{~N}$ & $1761 \mathrm{~N}$ & $1530 \mathrm{~N}$ \\
\hline & $15^{\circ}$ & $1600 \mathrm{~N}$ & $1900 \mathrm{~N}$ & $1365 \mathrm{~N}$ & $1680 \mathrm{~N}$ & $1880 \mathrm{~N}$ & $1400 \mathrm{~N}$ \\
\hline & $25^{\circ}$ & $1423 \mathrm{~N}$ & $1554 \mathrm{~N}$ & $1374 \mathrm{~N}$ & $1490 \mathrm{~N}$ & $1644 \mathrm{~N}$ & $1400 \mathrm{~N}$ \\
\hline
\end{tabular}

Fig. 1 Analysis of the exertion on L5/S1 using 3D SSPP, case A.

alt-text: Fig. 1

\begin{tabular}{|c|c|c|c|c|c|c|c|}
\cline { 2 - 8 } \multicolumn{2}{c|}{} & \multicolumn{3}{c|}{ nozzle's weight: $3 \mathrm{~kg}$} & \multicolumn{3}{c|}{ nozzle's weight: $4 \mathrm{~kg}$} \\
\hline $\begin{array}{c}\text { Axial } \\
\text { rotation }\end{array}$ & $\begin{array}{c}\text { Lateral } \\
\text { bending }\end{array}$ & Flexion $=35^{\circ}$ & Flexion= $60^{\circ}$ & Flexion $=80^{\circ}$ & Flexion= $35^{\circ}$ & Flexion= $60^{\circ}$ & Flexion= $80^{\circ}$ \\
\hline \multirow{3}{*}{$0^{\circ}$} & $0^{\circ}$ & $1820 \mathrm{~N}$ & $2600 \mathrm{~N}$ & $1988 \mathrm{~N}$ & $2205 \mathrm{~N}$ & $2519 \mathrm{~N}$ & $2013 \mathrm{~N}$ \\
\cline { 2 - 8 } & $15^{\circ}$ & $2196 \mathrm{~N}$ & $2505 \mathrm{~N}$ & $1960 \mathrm{~N}$ & $2145 \mathrm{~N}$ & $2515 \mathrm{~N}$ & $1990 \mathrm{~N}$ \\
\cline { 2 - 8 } & $25^{\circ}$ & $2091 \mathrm{~N}$ & $2511 \mathrm{~N}$ & $2025 \mathrm{~N}$ & $2185 \mathrm{~N}$ & $2364 \mathrm{~N}$ & $2050 \mathrm{~N}$ \\
\hline \multirow{3}{*}{$15^{\circ}$} & $0^{\circ}$ & $2238 \mathrm{~N}$ & $2494 \mathrm{~N}$ & $2484 \mathrm{~N}$ & $2274 \mathrm{~N}$ & $2489 \mathrm{~N}$ & $2524 \mathrm{~N}$ \\
\cline { 2 - 8 } & $15^{\circ}$ & $2235 \mathrm{~N}$ & $2915 \mathrm{~N}$ & $2678 \mathrm{~N}$ & $2330 \mathrm{~N}$ & $2870 \mathrm{~N}$ & $2732 \mathrm{~N}$ \\
\cline { 2 - 8 } & $25^{\circ}$ & $2222 \mathrm{~N}$ & $2531 \mathrm{~N}$ & $2430 \mathrm{~N}$ & $2315 \mathrm{~N}$ & $2664 \mathrm{~N}$ & $2453 \mathrm{~N}$ \\
\hline \multirow{3}{*}{$25^{\circ}$} & $0^{\circ}$ & $2208 \mathrm{~N}$ & $2743 \mathrm{~N}$ & $2400 \mathrm{~N}$ & $2294 \mathrm{~N}$ & $2662 \mathrm{~N}$ & $2427 \mathrm{~N}$ \\
\cline { 2 - 8 } & $15^{\circ}$ & $2342 \mathrm{~N}$ & $2820 \mathrm{~N}$ & $2300 \mathrm{~N}$ & $2417 \mathrm{~N}$ & $2790 \mathrm{~N}$ & $2343 \mathrm{~N}$ \\
\cline { 2 - 8 } & $25^{\circ}$ & $2118 \mathrm{~N}$ & $2398 \mathrm{~N}$ & $2270 \mathrm{~N}$ & $2184 \mathrm{~N}$ & $2485 \mathrm{~N}$ & $2300 \mathrm{~N}$ \\
\hline
\end{tabular}

Fig. 2 Analysis of the exertion on L5/S1 using 3D SSPP, case B.

alt-text: Fig. 2

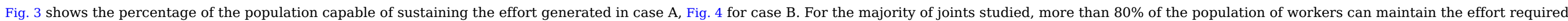
for both cases. Workers with shorter height seem more at ease with this task.

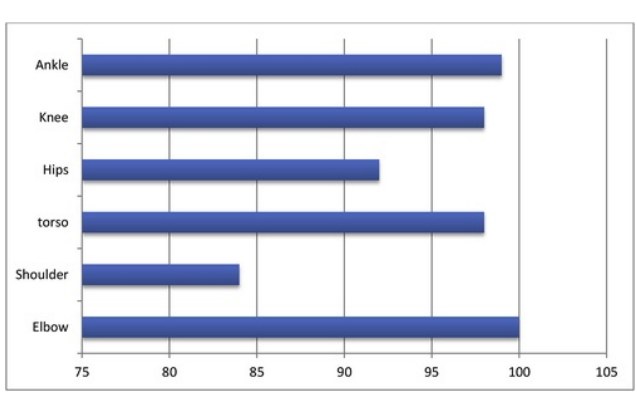

Fig. 3 Percentage of the population capable of maintaining the required effort, 3D SSPP study, case A.

alt-text: Fig. 3 


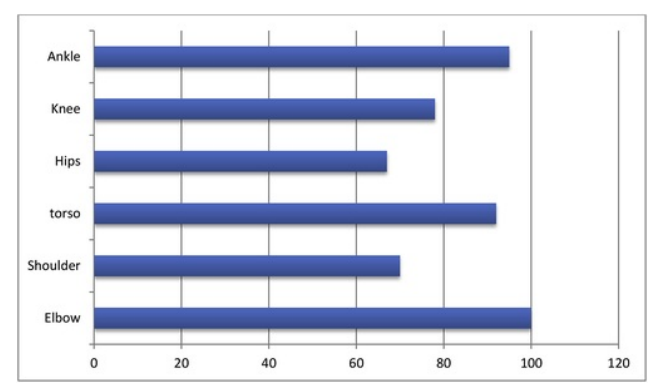

Fig. 4 Percentage of the population capable of maintaining the required effort, 3D SSPP study, case B.

alt-text: Fig. 4

\subsection{Analysis of muscle exertion of the nape of the neck and shoulders}

During deicing activities, the technicians must at times abduct the shoulder. These movements most frequently occur when:

- Activating the controls of the basket (to move the truck, and to raise or lower or laterally move the basket). Abduction is of approximately $60^{\circ}$

- Spraying the deicing fluids. Abduction varies between $60^{\circ}$ and $90^{\circ}$;

- Verbally communicating with other members of the deicing team. The technician must then raise his/her arms to reach his/her microphone. Abduction of approximately $60^{\circ}$.

These abductions are not preoccupying for the majority of the population of workers (2013Lehto and Buck, 2008).

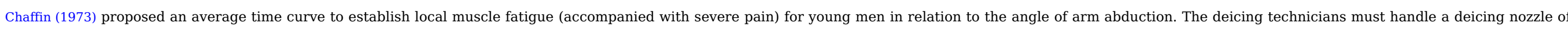

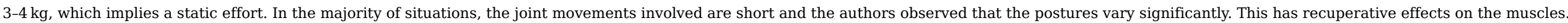

\subsection{Analysis of exertion when the arms are extended to do work beyond the reach zone}

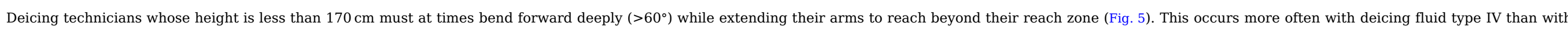

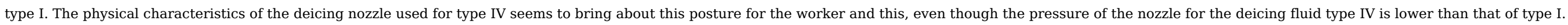

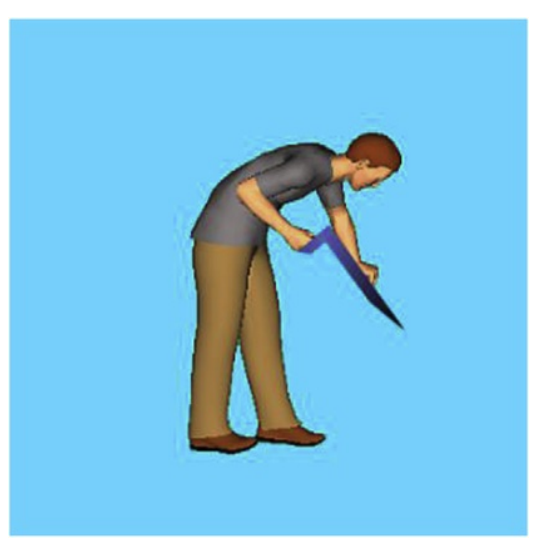

Fig. 5 Posture showing pronounced sagittal bending while extending arms to do work beyond the reach zone.

alt-text: Fig. 5 
whereby

\section{$\mathrm{F}=$ force of compression on L5/S1 (N)}

$\mathrm{b}=$ constant used to take into account the posture of the trunk

$\mathrm{m}=$ constant of weight

$\mathrm{L}=$ weight of the object $(\mathrm{kg})$

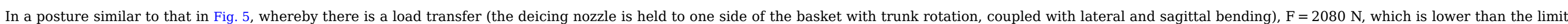
recommended by the NIOSH of $3400 \mathrm{~N}$ for men and $2600 \mathrm{~N}$ for women.

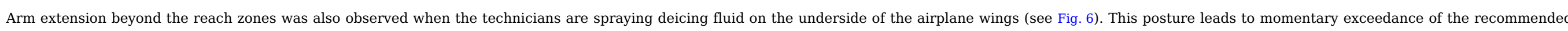
limits stated by Diffrient et al. (1990) for the deltoid, supraspinatus and subscapularis muscles.

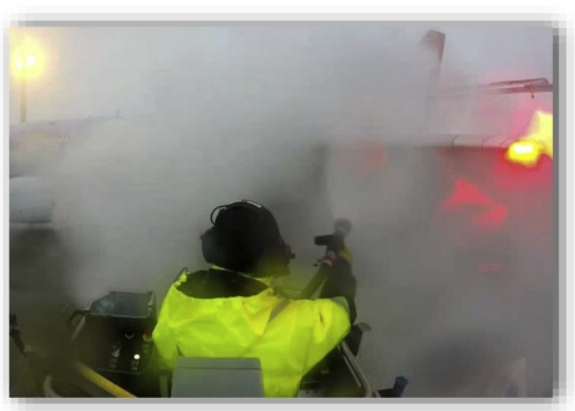

Fig. 6 Arm extension beyond the reach zone spraying deicing fluid on the underside of the airplane wings. alt-text: Fig. 6

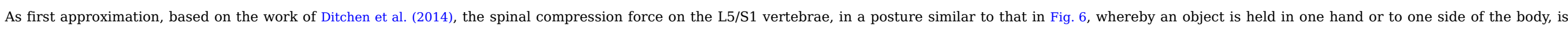
$\mathrm{F}=1055 \mathrm{~N}$, which is less than the limits recommended by the NIOSH.

\section{Discussion}

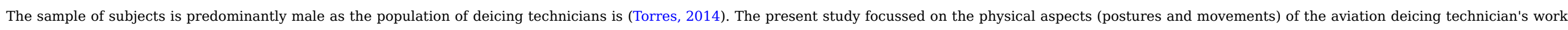

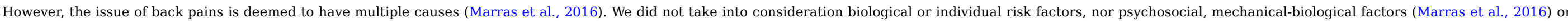
organisational factors (Marras, 2012).

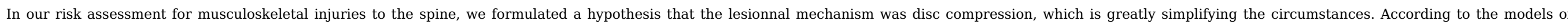

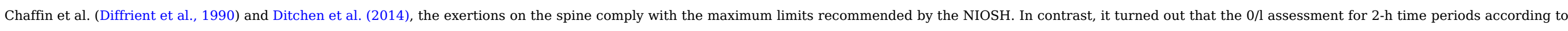

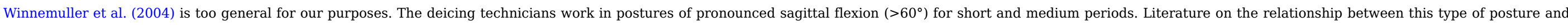

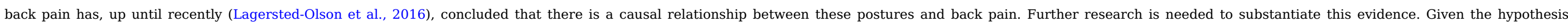

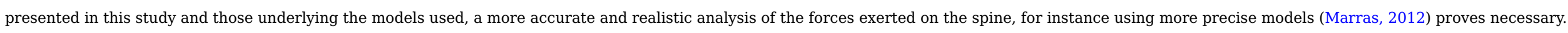




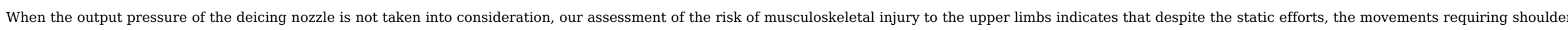

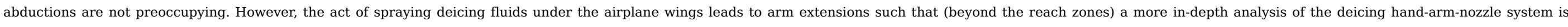
imperative.

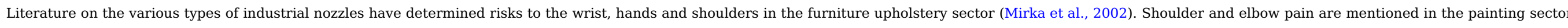

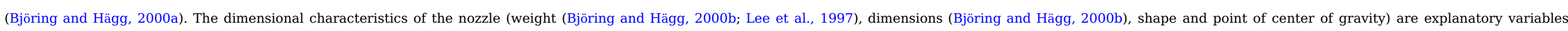

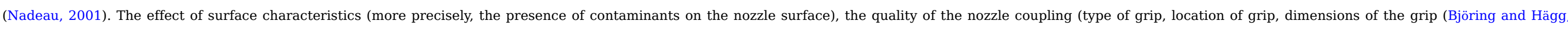

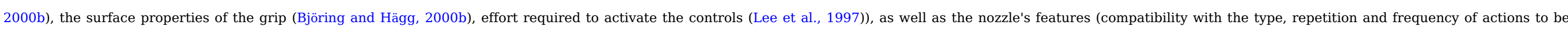

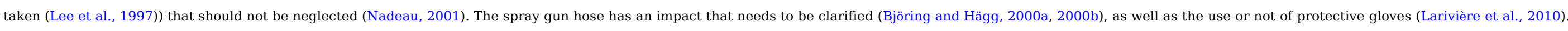
The latter can hamper efforts to grasp the tool's handle or to press its trigger (Radwin, 1996).

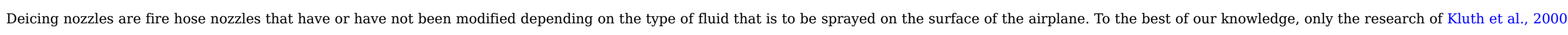

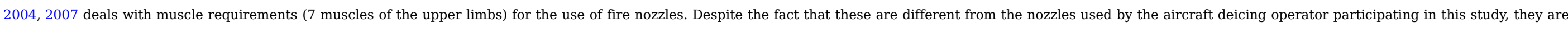

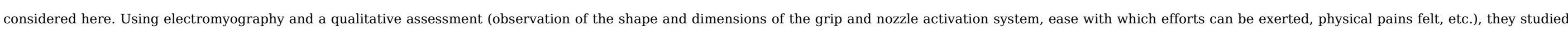

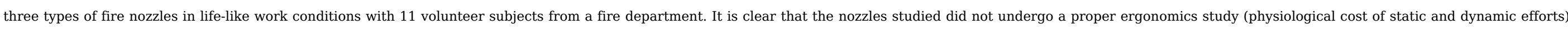
and that certain physical characteristics of these nozzles (type and shape of grip, type of controls and activation mechanism) need improvement.

This study did not consider the influence of strategies used by the deicing technicians such as leaning their body on the basket's guardrail or grasping the top rail (Jones et al., 2013, 2015).

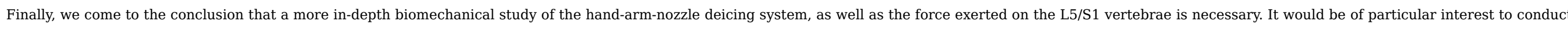

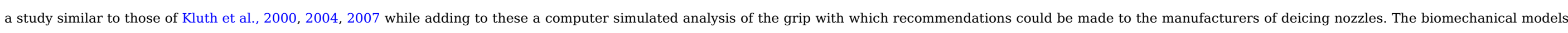
recently proposed in the literature (Desmoulins et al., 2014) could also prove useful.

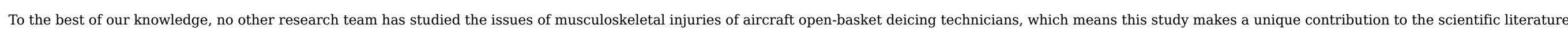
on this little-known profession.

\section{Conclusion}

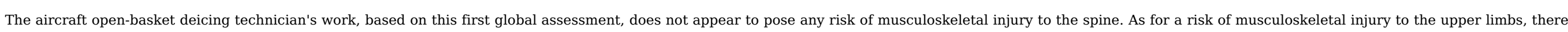
is cause for concern. A more in-depth ergonomics study of the hand-arm-nozzle deicing system and of the forces exerted on the L5/S1 vertebrae is recommended.

\section{Uncited references}

Arjmand et al., 2015; Chaffin et al., 2006; Chander and Cavatorta, 2017; David, 2005; Lehto and Buck, 2008; Schaub et al., 2013.

\section{Acknowledgments}

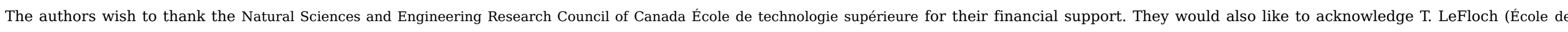
technologie supérieure) for the on-field work.

\section{References}

Arjmand N., Amini M., Shirazi-Adl A. and Plamondon A., Revised NIOSH lifting equation may generate spine loads exceeding recommended limits, Int. J. Ind. Ergon. 47, 2015, 1-8.

Björing G. and Hägg G.M., Musculoskeletal exposure of manual spray painting in the woodworking industry - an ergonomic study on painters, Int. J. Ind. Ergon. 26, 2000 ba, 603-614.

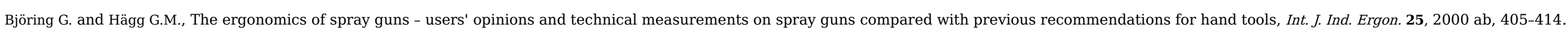




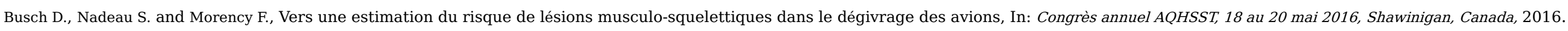

Chaffin D.B., Localized muscle fatigue: definition and measurement, J. Occup. Med. 15 (4), 1973, 346-354.

Chaffin D.B., Andersson G.B.J. and Martin B.J., Occupational Biomechanics, fourth ed., 2006, Wiley; Hoboken.

Chander D.S. and Cavatorta M.P., An observational method for postural ergonomic risk assessment, Int. J. Ind. Ergon. 57, 2017 , 32-41.

David G.C., Ergonomic methods for assessing exposure to risk factors for work-related musculoskeletal disorder, Occup. Med. 55, 2005, 190-199.

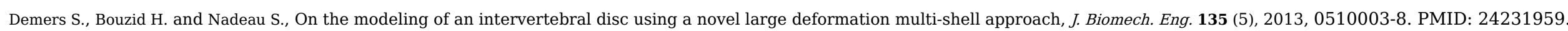

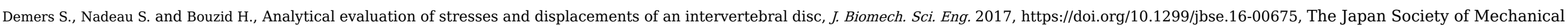
Engineers.

Desmoulins L., Michaud B., Allard P., Plamondon A. and Begon M., Cinématique et modélisation biomécanique de l'épaule lors de tâche de manutention, Rapport IRSST, R-8282014, 84 pages.

Diffrient N., Tilley A.R. and Bardagjy J.C., Humanscale 1/2/3, 1990, MIT Press.

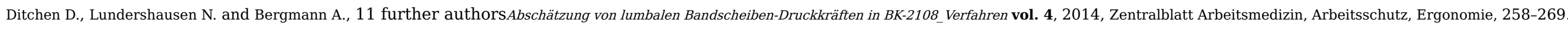

Jones M.L.H., Reed M.P. and Chaffin D.B., The effect of bracing availability on one-hand isometric force exertion capability, Ergonomics 56 (4), $2013,667-681$.

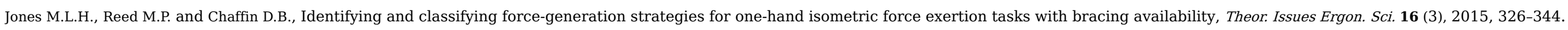

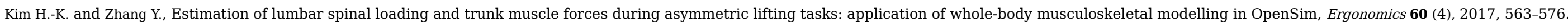

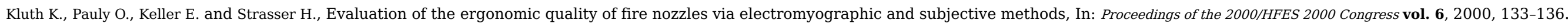

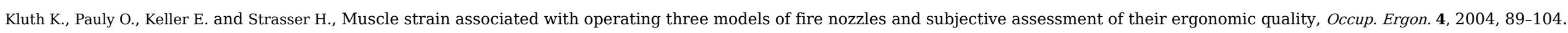

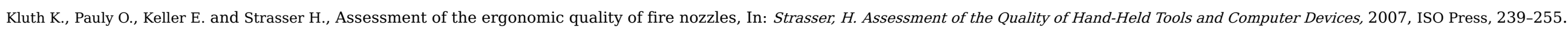

Kroemer K.H.E., Human strength, terminology, measurement, interpretation of data, Hum. Factors 20, 1970, 481-497.

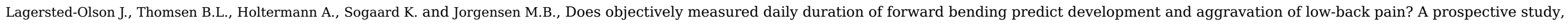
Scand. Work Environ Health 42 (6), 2016, 528-537.

Landau K., Nadeau S., Le Floch T. and Morency F., Ergonomic time and motion studies of aircraft de-icing work, J. Ergon. 7, 2017, 204, https://doi.org/10.4172/2165-7556.1000204.

Landau K., Nadeau S., Le Floch T. and Morency F., In: GfA, (Ed), Arbeitsprozesse und Wertschöpfungsbeiträge bei der Flugzeug-Enteisung, 2018a, Frühjahrskongress; Frankfurt, Beitrag A.4.3.

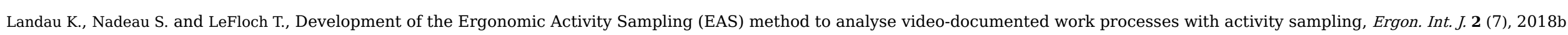

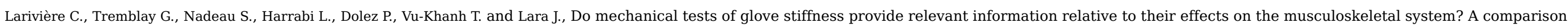
with surface electromyography and psychophysical methods, Appl. Ergon. 41 (2), 2010, 326-334.

Le Floch T., Nadeau S., Morency F. and Landau K., Physiological results of a stress-strain study for on-ground de-icing, In: GfA, (Ed), Frühjahrskongress, Frankfurt, Beitrag A.4.4, 2018.

Lee C.-C., Nelson J.E., Davis K.G. and Marras W.S., An ergonomic comparison of industrial spray paint guns, Int. J. Ind. Ergon. 19, 1997, 425-435.

Lehto M.R. and Buck J.R., Human Factors and Ergonomics for Engineers, 2008, Taylor and Francis, 969 pages.

Marras W.S., The complex spine: the multidimensional system of causal pathways for low-back disorders, Hum. Factors 54 (6), 2012, 881-889. 
Marras W.S., Walter B.A., Purmessur D., Mageswaran P. and Wiet M.G., The contribution of biomechanical-biological interactions of the spine to low back pain, Hum. Factors 58 (7), 2016, 965-975.

Mirka G.A., Shivers C., Smith C. and Taylor J., Ergonomic interventions for the furniture manufacturing industry. Part II - handtools, Int. J. Ind. Ergon. 29, 2002 , 275-287.

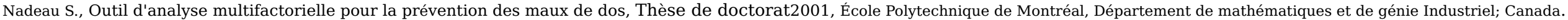

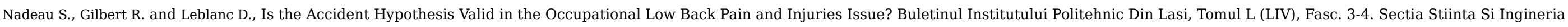
Materialelor, 2004, 63-68.

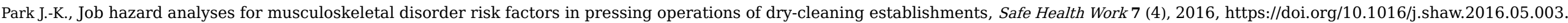

Radwin J.T., An Ergonomics Guide to Hand Tools, 1996, American Industrial Hygiene Association, 39 pages.

Schaub K., Caragnano G., Britzke B. and Bruder R., The European assembly worksheet, Theor. Issues Ergon. Sci. 14 (6), 2013, 616-639.

Task Force Tips, Manual: Ice-Control Anti-icing \& Deicing Nozzles, Instructions for Safe Operation and Maintenance, LIB-205 May 21, Rev13, 2013, 20 pages.

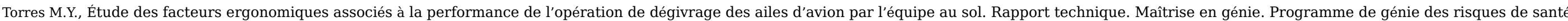
et de sécurité du travail, 2014, École de technologie supérieure, 127 pages.

Torres Y., Nadeau S. and Morency F., Study of fatigue and workload among aircraft de-icing technicians, Occup. Ergon. 13 (2), 2016, 79-90.

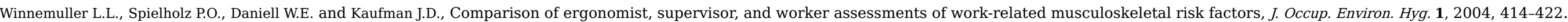

\section{Highlights}

- Compression of the lumbar rachis complies with the limits established by international recommendations.

- Some postures and movements of the upper limbs are preoccupying.

-

\section{Queries and Answers}

Query: Highlights should only consist of " 125 " characters per bullet point, including spaces. The highlights provided are too long; please edit them to meet the requirement.

Answer: Corrected

Query: Please check the article title and correct if necessary.

Answer: Checked

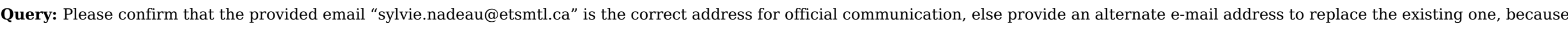
private e-mail addresses should not be used in articles as the address for communication.

Answer: Professional email provided

Query: Please check that the affiliations link the authors with their correct departments, institutions, and locations, and correct if necessary.

Answer: Checked 


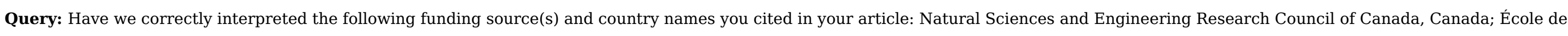
technologie supérieure, Canada?

Answer: Yes

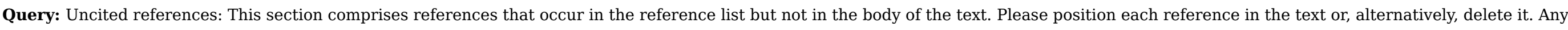
reference not dealt with will be retained in this section. Thank you.

Answer: Corrections done

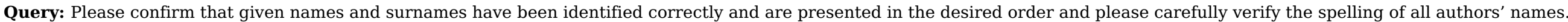
Answer: Checked

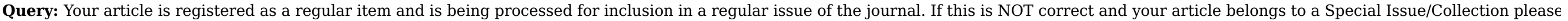
contact p.salma@elsevier.com immediately prior to returning your corrections.

Answer: Regular issue 